\title{
MTAP Gene
}

National Cancer Institute

\section{Source}

National Cancer Institute. MTAP Gene. NCI Thesaurus. Code C103994.

This gene plays a role in purine salvage. 